\title{
What is rhetoric anyway? Briared in words in Early China
}

\author{
Indraccolo, Lisa
}

\begin{abstract}
The present article explores the applicability of the term "rhetoric" in a non-Western context and, in particular, the legitimacy of such an attempt in the case of Early China, where the Warring States period is traditionally considered as the golden age of early Chinese "rhetoric". The pre-imperial and early imperial received literature provides good evidence for the employment of a well-established and clearly defined set of argumentative techniques in everyday political practice in ancient China. No handbook on such techniques has been handed down, and a proper term to define them as part of a broader, more structured activity that could match Western "rhetoric" does not appear until the medieval period. The article argues, however, that by applying a more fluid concept of "rhetoric" and by extending its scope beyond and across cultural boundaries it is not only possible but also legitimate to a certain extent to talk about a rhetorical tradition in the case of ancient China as well.
\end{abstract}

DOI: https://doi.org/10.1515/asia-2014-0019

Posted at the Zurich Open Repository and Archive, University of Zurich

ZORA URL: https://doi.org/10.5167/uzh-99240

Journal Article

Published Version

Originally published at:

Indraccolo, Lisa (2014). What is rhetoric anyway? Briared in words in Early China. Asiatische Studien, 68(1):331-341.

DOI: https://doi.org/10.1515/asia-2014-0019 
2014 - VOLUME 68 - NUMBER 1

\section{ASIATISCHE STUDIEN ÉTUDES ASIATIQUES}

\section{ZEITSCHRIFT DER SCHWEIZERISCHEN}

ASIENGESELLSCHAFT

REVUE DE LA SOCIÉTÉ SUISSE-ASIE

EDITOR-IN-CHIEF

Rafael Suter, Zürich

DE GRUYTER 
EDITOR-IN-CHIEF Rafael Suter, Asien-Orient-Institut, Universität Zürich, Zürichbergstrasse 4, CH-8032 Zürich, Email: sag.editor@aoi.uzh.ch

EDITORIAL BOARD Blain Auer, Lausanne. Norman Backhaus, Zürich. Wolfgang Behr, Zürich. Daria Berg, St. Gallen. Maya Burger, Lausanne. David Chiavacci, Zürich. Bettina Dennerlein, Zürich. Karénina Kollmar-Paulenz, Bern. Anke von Kügelgen, Bern. Angelika Malinar, Zürich. Annemarie Mertens, Zürich. Silvia Naef, Genève. Maurus Reinkowski, Basel. Andrea Riemenschnitter, Zürich. Ulrich Rudolph, Zürich. Reinhard Schulze, Bern. Pierre Souyri, Genève. Raji C. Steineck, Zürich. Ingo Strauch, Lausanne. Christoph Uehlinger, Zürich. Nicolas Zufferey, Genève.

Publiziert mit Unterstützung der Schweizerischen Akademie der Geistes- und Sozialwissenschaften. Publiée avec le soutien de l'Académie suisse des sciences humaines et sociales.

Published with the support of the Swiss Academy of Humanities and Social Sciences. 


\section{Inhaltsverzeichnis - Table des Matières - Contents}

Ulrich Rudolph

In eigener Sache — iii

Robert H. Gassmann

Rechenschaftsbericht 2013 - v

\section{Aufsätze - Articles - Articles}

Isabelle Charleux

Recent research on the Maitreya Monastery in Inner Mongolia (China) - 1

Samuel Guex

LeShinagakuet la modernisation de la sinologie japonaise -65

Rens Krijgsman

Traveling sayings as carriers of philosophical debate: From the intertextuality of the *Yucong 語叢 to the dynamics of cultural memory and authorship in Early China -83

Ğappar Rähimi (Rohlani)

Die Geschichte der Egiz Eriq Hुoğilar („Hoch-Graben Hูoğās“) in Qarqaš - eine orale Tradition aus Hotän, Süd-Xinjiang — 117

Heinrich Reinfried

„Wissen“ und „glauben“ als Gegensatzpaar im politischen Diskurs Japans zwischen 1812 und 1911 — 139

Bedeutungen von „Schutz“ in den japanischen Religionen: Beiträge der Sektion „Religion“ des 15. Deutschsprachigen Japanologentages, Zürich, 28.-30. August 2012

Katja Triplett

Sondersektion: Bedeutungen von „Schutz“ in den japanischen Religionen Einleitende Bemerkungen — 183 
Christian Göhlert

Anzan Kigan. Rituelle Geburtspraktiken Japans im Wandel der Zeit — 189

Niels Gülberg

Schutz durch magische Formeln. Amulette (o-fuda) des japanischen Strahlenglanz-Dhārạ̣i-Glaubens aus der Sammlung Kadono Konzen bunko 233

Bernhard Scheid

Wer schützt wen? Hachimanismus, Buddhismus und Tennōismus im Altertum -263

Daniel Schley

Zu den religiösen Aspekten tugendhafter Politik (tokusei) zum Schutz von Herrscher und Volk im frühen Mittelalter — 285

\section{Beiträge zur 7. Nachwuchstagung der Schweizerischen} Asiengesellschaft, Zäziwil, 17.-20. April 2013 Contributions aux 7èmes journées de la relève de la Société Suisse-Asie à Zäziwil, 17-20 avril 2013

Nadia Cattoni

Le développement desnāyikābhedas de la littérature sanskrite à la littérature braj: la naissance d'un genre — 317

Lisa Indraccolo

What is "rhetoric" anyway? Briared in words in Early China — 331

Lilian Iselin

Guerilla-Feldforschung im tibetischen Hochland: Ethische und praktische Herausforderungen -343

Kata Moser

Martin Heidegger in der Rezeption von Șifā' 'Abd as-Salām Ğa'far Zeitgenössische Überlegungen zum Verhältnis von Philosophie und Theologie 357 
Marie Wyss

De la relation entre les « nouvellesnianhua» et lesnianhua populaires :

exemples d'intericonicité dans un art de propagande - 373

\section{Rezensionen - Comptes rendus - Reviews}

Ayaka Löschke

Foljanty-Jost, Gesine / Hüstebeck, Momoyo (Hrsg.): Bürger und Staat in

Japan -401

Justyna Jaguścik

Huber, Jörg / Zhao Chuan (eds.): The Body at Stake. Experiments in Chinese

Contemporary Art and Theatre - 407

Elena Louisa Lange

Karatani, Kōjin: Auf der Suche nach der Weltrepublik — 413

Urs Gösken

Michaelsen, Marcus: Wir sind die Medien. Internet und politischer Wandel in

Iran -423

Takemitsu Morikawa

Ziltener, Patrick: Regionale Integration in Ostasien. Eine Untersuchung der

historischen und gegenwärtigen Interaktionsweisen einer Weltregion - 427 


\title{
Lisa Indraccolo
}

\section{What is "rhetoric" anyway? Briared in words in Early China*}

\begin{abstract}
The present article explores the applicability of the term "rhetoric" in a non-Western context and, in particular, the legitimacy of such an attempt in the case of Early China, where the Warring States period is traditionally considered as the golden age of early Chinese "rhetoric". The pre-imperial and early imperial received literature provides good evidence for the employment of a well-established and clearly defined set of argumentative techniques in everyday political practice in ancient China. No handbook on such techniques has been handed down, and a proper term to define them as part of a broader, more structured activity that could match Western "rhetoric" does not appear until the medieval period. The article argues, however, that by applying a more fluid concept of "rhetoric" and by extending its scope beyond and across cultural boundaries it is not only possible but also legitimate to a certain extent to talk about a rhetorical tradition in the case of ancient China as well.
\end{abstract}

Lisa Indraccolo: URPP Asia and Europe, University of Zurich. E-mail: lisa.indraccolo@uzh.ch

The Warring States period (475-221 B.C.) was characterized by the fragmentation of the central political power, as the legitimate Zhōu 周 dynasty (1122/1045-221 B.C.) was gradually divested of its authority by local rulers reigning over satellite states, formerly under the political, religious and cultural influence of the Zhōu kings. However, the Warring States period was not only an epoch of political and social turmoil, but it is also considered as the golden age of Chinese "rhetoric" and the epoch of the maximum flourishing of early Chinese politico-philosophical debate. The development of such a stimulating intellectual environment is a direct consequence of the increased level of personal physical mobility and the

\footnotetext{
* I would like to thank Wolfgang Behr, Matthias Richter, James Weaver and the anonymous reviewers for Asiatische Studien/Études asiatiques for their insightful comments on previous drafts of this article. This article is based on a paper presented at the 7. Nachwuchstagung/7èmes Journées de la relève 2013 of the Schweizerische Asiengesellschaft (SAG), the Schweizerische Gesellschaft Mittlerer Osten und Islamische Kulturen (SGMOIK) and the URPP Asia and Europe, Zäziwil, Switzerland, April 2013.
} 
consequent intensified exchange of ideas across borders, ${ }^{1}$ a phenomenon epitomized by the figure of the "wandering persuader".

“Wandering persuaders” (variously called yóushui 游說 ${ }^{2}$, yóushi 游士, yóushui jiā 游說家, yóután zhī shì 游談之士, ${ }^{3}$ or yóushuì zhī shì 游說之士 ${ }^{4}$ ) are the main protagonists of "Masters texts" (zǐshū 子書) and are described in the received literature as political advisers and diplomats ${ }^{5}$ travelling from court to court, and as shrewd and skilled debaters who had mastered the two main classical Chinese polemical techniques of “argumentation” (biàn 辯) and "persuasion” (shui 說). ${ }^{6}$ These persuaders in most cases were retainers at the courts of local rulers, anx-

1 See for instance Pines 2009 and 2012; Hsu 1965.

2 Kroll 1985: 126.

3 Kern 2000: 229.

4 Shǐji, juàn 46, Tiánjìng zhòngwán shìjiā dì shíliù 史記卷四十六田敬仲完世家第十六 (1963: 1895). A shì 士, according to Crump (1964: 2), is a "specialist in governing [. . .] a man who has learning [...] offering his service."

5 For a description of their mastering of dialectics see Levi 1992: 51-52. Oliver (1971: 84) classifies yóushui (or yóushì) in three categories: storytellers, professional persuaders operating at feudal courts and diplomatic agents. However, at least the last two categories overlapped most of the time, as functionaries were often sent as envoys (shǐ 使) abroad. On this topic, see also Xing Lu (1998: 80), who defines yóushuì as "persons who engaged in shui (N/A persuasion) activity by travelling around and acting as political consultants to kings of various states".

6 Biàn (argumentation) and shuì (persuasion) are two complementary dialectical techniques, the use of which is widely attested in pre-imperial and early imperial classical Chinese literature. Cases of biàn usually involve one or, at times, more speakers engaging in an animated debate, which in most cases takes place at court and can even be performed as a sort of court entertainment. Examples of this kind of polemical technique seem rather sketchy and dry, in some extreme cases reduced to a sort of play script if deprived of any further contextualization. They typically assume the form of a dialectical skirmish between a persuader and one or more opponents debating over mainly abstract problems. Far from being exclusively speculative, these discussions are often "translated" into other more pragmatic contexts to tackle diplomatic issues or political questions of general interest. In cases of argumentation, the two sides involved in the discussion are characterized by a situation of social equality and the public does not seem to influence the way in which arguments are presented and discussed by persuaders. The main goal of a persuader seemingly is to outtalk his opponent by twisting his words and using his own arguments against him, often employing the technique of reductio ad absurdum, until the opponent falls into contradiction, is left speechless or is forced to accept the persuader's point of view. Instances of shui are elaborated dialogues conceived as written texts with an explicit persuasive intent, and are often embedded in a narrative framework that contextualizes the setting and the occasion of the speech. These fictive dialogues, usually taking place at court, may involve two or more speakers and are generally characterized by a situation of social disparity between the speaker and the addressee. Cases of persuasion are always situational and stress is put on the audience. They typically assume the form of a plea to a sovereign or a superior in rank, aimed at convincing the addressee to agree on some key ethical or political issue, to undertake an advisable course of action or to assume a certain desirable behavior. For a more detailed 
ious of gaining fame, effective advice for rule and pragmatic strategies to help them preserve and enlarge their domains.

The present study problematizes the applicability of the term "rhetoric" in the context of early China, and aims at exploring the range and scope of its use, in particular in relation to the activity of "wandering persuaders" as represented in the received literature.

The term "rhetoric" as applied to the Chinese context - where "term" is meant as the linguistic manifestation and expression in speech of a certain given concept - is considered highly problematic in contemporary sinological discourse, and its employment is a heatedly debated issue since it immediately evokes the Ancient Greek and Roman traditions. In these traditions, rhetoric is acknowledged as a proper literary genre and a well-established technique. Moreover, in the Western Classical world the separation between rhetoric and philosophy is fairly clear-cut at least since Socrates' and Plato's first distinction of the two disciplines. ${ }^{7}$ In contrast, in ancient China, the boundaries between the two disciplines overlap to a large extent, to the point that early Chinese texts, in particular those classified as Masters texts, present a somewhat hybrid form. Such peculiarity requires us to rethink the predominant Western conception of "rhetoric" in a more fluid and dynamic way, and to broaden its scope in the attempt to reconcile these two somewhat competing aspects in the Classical Chinese tradition. ${ }^{8}$

Before testing the possible range and limit of applicability of the term "rhetoric" in the Classical Chinese tradition, it is, first and foremost, necessary to address a few basic questions, clarifying the meaning of the term in this specific context, and the nature of the different phenomena that can be potentially identified and, at least to a certain extent, coherently grouped together as pragmatic manifestations of a Chinese "rhetoric". Moreover, the nature of this Chinese "rhetoric" itself should be further investigated in order to ascertain whether it complies with the characteristics of a literary genre, a specific and identifiable discipline or a proper oratorical technique.

There is, in fact, no way to determine exactly how rhetoric was taught and transmitted in early China, since no programmatic or didactic text on rhetoric as such has been handed down. Nevertheless, there is abundant evidence of the practice and the performance of rhetoric as a dialectical technique in the written

description of these two techniques see Reding 1985; Xing 1998, esp. 68-89; Kern 2000; Garrett 1993; Goldin 1993; Kroll 1985; Crump 1964 and 1999.

7 For a broad and detailed analysis of the distinction between the philosopher and the rhetorician/sophist in Platonic dialogues see McCoy 2008.

8 Denecke 2010. 
accounts of the activity of wandering persuaders as preserved in Masters texts and historiographical sources.

A fundamental though necessarily brief digression on the general characteristics of Masters texts ${ }^{9}$ must be made here. Masters literature is a Hàn 漢 (206 BC-220 AD) literary category identifying a bulk of received texts named after historical and pseudo-historical "masters of thought" of the Warring States period. According to the tradition, these eponymous dialecticians would have authored or at least co-authored Masters texts. ${ }^{10}$ However, the texts belonging to this category should not be considered as an accomplished literary product that was conceived and composed in writing as the coherent expression of the thought of an author. In fact, Masters texts have a composite nature and a multilayered textual history, and should rather be considered as the complex result of subsequent stages of accretion, emendation and editorial polishing undertaken mostly during the Hàn period ${ }^{11}$.

Masters texts neither provide a progressive or coherent exposition of the thought of an individual thinker, nor do they show the presence of a consistent unitary authorial voice. They are, rather, heterogeneous collections of dialogues, anecdotes, sayings, or treatises on disparate subjects that typically present a political, ethical or didactic content and a marked rhetorical or polemical tone. In particular, dialogues and anecdotes provide the ideal setting for staging cases of argumentation and persuasion, which, as remarked above, are the fundamental polemical techniques employed by "wandering persuaders" in narrative action. Such written accounts constitute a rich and varied repository of examples of what can be properly identified as the literary evidence of the performance of rhetoric in ancient China. They typically assume three main forms: the court debate between persuaders, the plea to a sovereign or a superior in rank and the teaching scene, involving a master imparting an essentially oral teaching to his disciples, though of course exceptions to this framework do occur.

As often happens, taxonomies and definitions are already anachronistic in the very same moment in which they start to be applied in a more or less systematic way. In this sense, "Masters literature" is no exception, as this label did not exist during the Warring States period, but was created only in a second moment, during a later, early imperial bibliographical enterprise that found its expression in an all-encompassing project of systematization and canonization of the cul-

9 See p. 1.

10 On the issue of authorship in early Chinese texts see Petersen 1995; Nylan 2000; Csikszentmihalyi and Nylan 2003; Schwermann 2009; Kern 2005; Beecroft 2010.

11 See Boltz 1997; Kern 2001, 2002 and 2005, see in particular William Boltz's contribution (2005: 50-78); Giele 2003, especially 409-416; Shaughnessy 2006; Hunter 2012; Richter 2013. 
tural heritage preserved in the Imperial Library during the Hàn period. Therefore, Masters literature is indeed a Hàn literary category superimposed a posteriori on earlier heterogeneous clusters of texts, whose original core material might be possibly traced back to the Warring State period. ${ }^{12}$

Though we can assume that at least the core of Masters texts as we know them today dates back to a much earlier period, still there is no reliable way to ascertain to what extent editors and collators intruded into the texts. From this perspective, these works should not be considered as a truthful representation of Warring States society or as presenting reliable accounts of historical events, but rather as proper literary products.

Not only are we unable to recover the "original" context in which the materials included in these texts were elaborated and circulated - an enterprise that was most probably hard if not impossible already for the compilers/editors of Masters texts - but also the term "original” itself in this context is substantially deprived of meaning. As Bakhtin underlines, "the text - printed, written, or orallyrecorded - is not equal to the work as a whole [...]. The work also includes its necessary extratextual context in which it is understood and evaluated (of course, this context changes in the various epochs in which it is perceived, which creates a new resonance in the work"13. Therefore, reading these texts today as during the Hàn period - cannot be atemporal nor objective, but must always be "dialogic" and in time. As texts assume a multidimensional referentiality, the reader is faced with what Bakhtin calls "the eternal renewal of meaning in all new context"14. Thus reading must always be contextual, and interpretation of these texts proceeds and develops as a dialogic and relational process, as through this (re)reading compositional elements of the text become embedded in a new con-text. From this point of view, the contents exposed in these texts are not only up-to-date and perpetually renewed, but become also meaningful beyond their restricted temporal and cultural contingencies. ${ }^{15}$ As will be shown, this kind of process involves not only texts as such, but extends also to concepts.

12 At the same time, Masters literature also denotes the subsequent development of a flourishing literary production that evolved, mimicking and appropriating the characteristics of the materials assembled together and systematized by the Hàn editors. Brand new texts in this Masters-style, displaying the characteristics of the genre, continued to be produced and proliferated until the end of the early Medieval period (Tian 2006, esp. 473-474).

13 Bakhtin 1986: 166-167.

14 Bakhtin 1986: 169.

15 As Northrop Frye puts it, "each reader, translator or recreator, renders his text into a form determined largely by his own cultural context. [.. .] the arts form an extension of our own past, but find their meaning for us in our present situation. That present situation contains elements of vision which we project on the future, and those elements form the recreating aspect of our 
Apparently, the dismissal of a Chinese rhetoric is largely determined by the euro-centric conception that rhetoric embodies a phenomenon almost exclusive to and primarily confined within the experiences of the Western Classical world. However, assuming such a restrictive approach would also theoretically mean denying de facto other equally rich and more attested rhetorical traditions their validity, such as Indian Buddhist rhetoric. Choosing a Chinese autochthonous term to identify early Chinese "rhetoric" might still seem an appropriate and convenient solution that could eliminate any possible ambiguity or source of disagreement. Yet, while in the Warring States period there already existed a well-established terminology that clearly identified and distinguished the two main polemical techniques of argumentation and persuasion, there was apparently no proper term for "rhetoric". The first occurrence of a Chinese term roughly coterminous with rhetoric, xiūcí 修辭 (literally, “refined words") in a sense that comes somewhat close to our Western understanding of it can only be found in a later Medieval work, Liú Xié’s 劉劦思 (465-522 A.D.) Wénxīn diāolóng 文心雕龍 (The Literary Mind and the Carving of Dragons), ${ }^{16}$ which is the first extant work of literary criticism in the history of Chinese literature.

However, the term xiūcí is never used before and especially never appears in those very same texts that have been treated here as "rhetorical", that is Masters texts. Early Chinese "rhetoric" is a phenomenon that indeed exists and manifests itself in the Classical Chinese tradition, but whose identity and borders are blurred and not unambiguously identified in the speech conventions within this very same tradition. Thus, the term xiūcí is as anachronistic and alien to the Warring States practice of argumentation and persuasion under inquiry as any other term borrowed from within or without the later Chinese tradition, and from any other foreign traditions, including, obviously, the Western Classical tradition of "rhetoric".

A possible solution to this impasse would be to coin a brand new term, though analogous attempts at molding new terms for Classical Chinese concepts have already revealed their intrinsic limits and sterility. In the 1950s, Peter Boodberg's

reading. Every work of literature that we continue to read and study meant something to its own time and something quite different to us. Both poles of understanding have to be kept in mind. If we disregard its original historical context, we are simply kidnapping it into the orbit of our own concerns; if we disregard its relevance to ourselves, we are leaving it unrevived in the morgue of the past. [...] One end of this process is a creation, and the other end is a recreation. (Frye 1980: 67)

16 The term appears in chapter 1 “Yuándào” 原道 (1 occurrence); chapter 3 “Zōngjīng” 宗經 (1 occurrence); chapter 10 “Zhùméng” 祝盟 (1 occurrence); chapter 28 “Fēnggǔ” 風骨 (5 occurrences); chapter 43 “Fùhuì” 附會 (1 occurrence); chapter 47 “Cáilüè” 才略 (3 occurrences). See Shih 1959; Liu Yongji 2007. 
(1953) experimental linguistic hybridization conjugating English and Latin in the rendering of a selection of Chinese terms produced a groundbreaking rereading of Classical Chinese Confucian concepts, proposing a few awkward though noteworthy results. The neologisms thus produced were short-lived but already fought against the uncritical dogmatic use of technical terms as if they bore a univocal meaning throughout the whole Classical Chinese tradition. Boodberg argued for the necessity of sinology rethinking and reinventing itself and its terminology in a more dynamic and original way, drawing from "the vast regions beyond the rim of the historical sphere of influence of our monotheistic psyche and our classical heritage" 17 . While his pioneering attempts at "judicious wordmongering across literary frontiers" 18 should undoubtedly be acknowledged as an inspiring and inspirational appeal, as they contributed to enliven and stir up a debate on terminology in the sinological academic community, his aim at univocal and clear-cut definitions of terms even within a single textual tradition - in the specific case the Confucian one - seems today rather quixotic.

Moreover, neither new concepts nor new terms for old concepts are necessary in order to address this issue and propose a concrete solution. A more desirable and functional approach would be to develop a different operational attitude to those already in use, in order to exploit what Mieke Bal defines as "the productive potential of concepts" 19 , facing in particular the issue of the traductability and translatabilty of concepts, accounting for a more fluid dialogue and "travel" 20 of these concepts across disciplines.

Concepts should be better understood as processes in action rather than static and monolithic matters-of-fact. As Bal further underlines, ${ }^{21}$ concepts are neither suitable definitions nor labels or dogmatic taxonomies but multifaceted cultural processes in fieri, the diachronic evolutionary potential and synchronic outreach of which must be accounted for. Moreover, as Gilles Deleuze and Félix Guattari remarked, a concept is never a simple unit but has "an irregular contour defined by the sum of its components"22, and can be seen as "a point of coincidence, a condensation, an accumulation of its own components" 23 . Due to their intrinsic complexity, ambiguity and "messiness" 24 , even ingrained concepts can

17 Boodberg 1953: 319.

18 Boodberg 1953: 332.

19 Bal 2012[2002]: 53.

$20 \mathrm{Bal}$ 2012[2002], see chapter 2, in particular 24-25.

$21 \mathrm{Bal}$ 2012[2002], esp. 22-29.

22 Deleuze/Guattari, 1994: 15-16. See also Bal 2012[2002], in particular chapter 2.

23 Deleuze/Guattari 1994: 20.

24 Bal 2012[2002]: 17. 
- and should - be constantly reworked, reinterpreted and adapted to meet new exigencies and circumstances.

Concepts are ideas moving in space and time, both synchronically and diachronically, across borders and disciplines. They are "neither fixed nor unambiguous" 25 , therefore any occurrence within a specific context has to be identified and properly assigned one of the possible meanings a concept entails and can potentially assume. Consequently, concepts might be tentatively conceived as a sort of hypernym, subsuming under themselves a whole range of possible meanings, so that the interpretation and use of a concept must always be situational and contextual.

Thus, the innate tendency to "Cratylism", that is the "desire for a perfect language of words univocal in meaning", a discourse that, as Genette pointed out, originally "comes down almost entirely to a set of texts, a corpus, perhaps better called a genre, whose founding text, the matrix and the program for the whole tradition [...] is precisely [...] Plato's Cratylus" ${ }^{26}$, collapses under "the extensive empirical evidence that language is imperfect and polyvocal in meaning" 27 . Consequently, terms as the linguistic manifestation of concepts are to be considered as inherently polyvalent and polysemantic, expressing what Bal calls the "plurisemic potential of the concept" 28 .

However, this polyvalence of concepts should not be considered as a narrowing of their scope or as a generalization - or, even worse - a trivialization of their meaning. As Deleuze and Guattari underline, "concepts [.. .] have their own way of not dying while remaining subject to constraints of renewal, replacement, and mutation. [.. . ] concepts constantly change" 29 . In fact, a multifunctional adaptability and plasticity is an intrinsic characteristic of concepts, and constant virulent variation is an almost physiological function they manifest.

From this perspective, the case of early Chinese "rhetoric" is not so much a matter of assimilation or domestication of a foreign term, but rather of the necessary extension of the semantic field of a term as it is usually interpreted in the West, so that it covers, comprises and reconciles in itself also the characteristics a particular manifestation of a phenomenon assumes within a specific cultural context and historical period.

Finally, instead of singling out the absolute otherness of the Chinese "rhetorical" tradition, it might be more profitable to try to reconcile it and stress its

25 Bal 2012[2002]: 23.

26 Genette 1995: 5.

27 Billitteri 2009: xiii.

28 Bal 2012[2002]: 15.

29 Deleuze/Guattari 1994: 8: see also Bal 2012[2002]: 32. 
continuity with the broader inter- and cross-cultural phenomenon that is global "Rhetoric". Therefore, we should not talk about a single homogeneous static concept of "rhetoric" that constantly repeats itself and can be acknowledged as such only if it presents a certain predefined stock of standard characteristics, but rather of "rhetorics" as different forms and local manifestations of a broader multifarious concept of Rhetoric, under which these individual manifestations are subsumed and in which they are reconciled. Accordingly, Chinese "rhetoric" should be considered as one of the possible manifestations of Rhetoric.

On this basis, it can be concluded that "rhetoric" as applied to Warring States literature is a potentially productive term that even anticipates its theoretical elaboration in the Chinese tradition itself, and seems a suitable operational tool flexible enough to be adapted and extended so as to encompass all the peculiar facets of Classical Chinese polemical discourse. Therefore, it seems not only possible but also to some extent legitimate to talk of a "rhetoric" and "rhetorical tradition" also in early China.

\section{Bibliography}

Bakhtin, Mikhail M. (1986): Speech Genres and Other Late Essays. Austin: University of Texas Press.

Bal, Mieke (2012 [2002]): Travelling Concepts in the Humanities - A Rough Guide. Toronto/ Buffalo/London: University of Toronto Press.

Beecroft, Alexander (2010): Authorship and Cultural Identity in Early Greece and China: Patterns of Literary Circulation. Cambridge/New York: Cambridge University Press.

Billitteri, Carla (2009): Language and the Renewal of Society in Walt Whitman, Laura (Riding) Jackson, and Charles Olson - The American Cratylus. New York: Palgrave Macmillan.

Boltz, William G. (1997): “Manuscripts with Transmitted Counterparts”. In: New Sources of Early Chinese History: An Introduction to the Reading of Inscriptions and Manuscripts. Berkeley: Society for the Study of Early China and the Institute of East Asian Studies, University of California, 253-283.

Boltz, William G (2005): “The Composite Nature of Early Chinese Texts”. In: Text and Ritual in Early China. Edited by Martin Kern. Seattle/London: University of Washington Press, 50-78.

Boodberg, Peter A. (1953): “The Semasiology of some Primary Confucian Concepts". Philosophy East \& West 2.4: 317-332.

Crump, James I. Jr. (1964): 戰國策 Intrigues: Studies of the Chan-kuo Ts'e. Ann Arbor: The University of Michigan Press.

Crump, James I. Jr. (1979): Chan-kuo Ts'e. San Francisco: Chinese Materials Center Inc.

Csikszentmihalyi, Michael / Nylan, Michael (2003): “Constructing Lineages and Inventing Traditions through Exemplary Figures in Early China”. T’oung Pao 89.1-3: 59-99.

Deleuze, Gilles / Guattari, Félix (1994): “What is a Concept?”. In: What is Philosophy? New York: Columbia University Press, 16-34. 
Denecke, Wiebke (2010): The Dynamics of Masters Literature - Early Chinese Thought from Confucius to Han Feizi. Cambridge (Mass.)/London: Harvard University Press.

Frye, Northrop (1980): Creation and Recreation. Toronto/Buffalo/London: University of Toronto Press.

Garrett, Mary M. (1993): “Classical Chinese Conceptions of Argumentation and Persuasion”. Argumentation and Advocacy 29.3: 105-115.

Goldin, Paul R. (1993): “Miching Mallecho: The Zhanguoce and Classical Rhetoric”. SinoPlatonic Papers 41: 1-27.

Genette, Gérard (1995): Mimologics - Mimologiques: voyage en Cratylie. Lincoln: University of Nebraska.

Giele, Enno (2003): “Using Early Chinese Manuscripts as Historical Source Materials”. Monumenta Serica 51: 409-438.

Hsu Cho-yun (1965): Ancient China in Transition: An Analysis of Social Mobility, 722-222 B.C., Stanford: Stanford University Press.

Hunter, Michael (2012): Sayings of Confucius, Deselected. Ph.D. Dissertation, Princeton University.

Kern, Martin (2000): “'Persuasion’ or ‘Treatise’? The Prose Genre Shui 說 and Shuo 說 in the Light of the Guwenci leizhuan of 1779”. In: Ad Seres et Tungusos - Festschrift für Martin Gimm zu seinem 65. Geburtstag am 25. Mai 1995. Edited by Lutz Bieg, Erling von Mende and Martina Siebert. Wiesbaden: Harrassowitz Verlag, 221-245.

Kern, Martin (2001): "Ritual, Text and the Formation of the Canon. Historical Transitions of 'wen' in Early China”. T’oung Pao 87.1-3: 43-91.

Kern, Martin (2002): "Methodological Reflections on the analysis of Textual Variants and the Modes of Manuscript Production in Early China”. Journal of East Asian Archaeology 4.1-4: 143-180.

Kern, Martin (ed) (2005): Text and Ritual in Early China. Seattle/London: University of Washington Press.

Kroll, Jurij L. (1985): “Disputation in Ancient Chinese Culture”. Early China 11-12: 119-145.

Levi, Jean (1992): “L’Art de la Persuasion à l'Epoque des Royaumes Combattants (Ve-IIle Siècles a.v. J.C.)". Extrême Orient-Extrême Occident 14: 49-89.

Liu Yongji 劉永濟 (ed.) (2007): Wenxin diaolong jiaoshi 文新雕龍校釋. Beijing: Zhonghua shuju.

McCoy, Marina (2008): Plato on the Rhetoric of Philosophers and Sophists. New York: Cambridge University Press.

Nylan, Michael (2000): “Textual Authority in Pre-Han and Han”. Early China 25: 205-258.

Oliver, Robert T. (1971): Communication and Culture in Ancient India and China. Syracuse: Syracuse University Press.

Petersen, Jens Østergaard (1995): “Which Books Did the First Emperor of Ch’in Burn? On the Meaning of Pai Chia in Early Chinese Sources". Monumenta Serica 43: 1-52.

Pines, Yuri (2009): Envisioning Eternal Empire - Chinese Political Thought of the Warring States Era. Honolulu: University of Hawai'i Press.

Pines, Yuri (2012): The Everlasting Empire - The Political Culture of Ancient China and Its Imperial Legacy. Princeton: Princeton University Press.

Raphals, Lisa (1992): Knowing Words - Wisdom and Cunning in the Classical Traditions of China and Greece. Ithaca/London: Cornell University Press.

Reding, Jean-Paul (1985): Les fondements philosophiques de la rhétorique chez les sophistes grecs et chez les sophistes chinois. Berne/Frankfurt/New York: Peter Lang. 
Richter, Matthias Ludwig (2013): The Embodied Text - Establishing Textual Identity in Early Chinese Manuscripts. Leiden: Brill.

Schwermann, Christian (2009), “Composite Authorship in Western Zhōu Bronze Inscriptions: The Case of the 'Tiānwáng guǐ 天亡篮” Inscription”, paper presented at the conference “'Birth of the Author': Authorial Presence, Authorial Consciousness and Concepts of Authorship in Pre-Modern Asian Literary and Philosophical Traditions”, University of Zurich.

Shaughnessy, Edward L. (2006): Rewriting Early Chinese Texts. Albany: State Univeristy of New York Press.

Shih, Vincent (tr.) (1959): The Literary Mind and the Carving of Dragons 文心雕龍 by Liu Hsie. Taipei: Chung Hwa Book Company Ltd.

Shiji (quan shi ce) 史記(全十冊) (1963): Beijing: Zhonghua shuju.

Tian Xiaofei (2006): “The Twilight of the Masters: Masters Literature (Zishu) in Early Medieval China”. Journal of the American Oriental Society 126.4: 465-486.

Xing Lu (1998): Rhetoric in Ancient China, fifth to third century B.C.E. - A Comparison with Classical Greek Rhetoric. Columbia, South Carolina: University of South Carolina Press. 
